\title{
ANALISIS KELAYAKAN FINANSIAL DAN STRATEGI PENGEMBANGAN USAHA INDUSTRI RUMAHAN GULA SEMUT (PALM SUGAR) DARI NIRA NIPAH DI KELURAHAN PALLANTIKANG
}

\author{
Irmawati ${ }^{1)}$, Husain Syam²), Jamaluddin²). \\ 1Alumni Program Studi Pendidikan Teknologi Pertanian \\ 2 dan ${ }^{3}$ Dosen PTP FT UNM \\ irmawatitahir30@yahoo.co.id
}

\begin{abstract}
This research is aim to know a work-development based on the supplying of nira nipah (sap of nipa palm) as a basic ingredient, production, labor, marketing, financialfeasibility, and work-development strategy. The subject of the study were 30 sap-incisor farmers and a palm sugar home industry in Pallantikang village. The feasibility analysis used were Benefit Cost Ration (BCR), Net Present Value (NPV), Internal Rate of Return (IRR), Break Event Point (BEP), and PBP (Pay Back Period) to know the feasibility of the work. SWOT matrices was used to build work-development strategy of the palm sugar home industry. The result of the study showed that the work-development strategy of a basic ingredient, production, labor, and marketing are suitably done in the research location. The financial-feasibility toward palm sugar home industry in Pallantikang village for the BCR, IRR, BEP (Unit), BEP (Rupiah), and PBP criterion is suitably done. Moreover, based on SWOT analysis, it is found a recommendation for this research that are increasing the operating income; work in cooperation with government to get a capital aid, tools, even training for the owner and the labors of palm sugar, and give a development and training for sap-incisors in order to not making ballo or fermented palm wine.
\end{abstract}

\section{Keywords: Sap-incisor, A Home Industry Of Palm Sugar, Feasibility Analysis, Strategy Development.}

\section{PENDAHULUAN}

Indonesia merupakan negara
agraris dimana mata pencaharian
penduduknya sebahagian besar adalah
disektor pertanian. Sektor ini
menyediakan pangan bagi sebahagian
besar penduduk dan memberikan
lapangan pekerjaan bagi semua angkatan
kerja yang ada. Salah satunya sebagai
bahan baku dalam kegiatan industri, baik
industri besar, industri menengah, industri
kecil maupun industri rumah tangga.
Pertanian adalah proses
menghasilkan bahan pangan, ternak,
serta prodak-prodak agroindustri dengan
cara memanfaatkan sumber daya

tumbuhan dan hewan. Pertanian merupakan aspek penting dalam pembangunan perekonomian Indonesia mulai zaman dahulu hingga sekarang ketika pertengahan 1997 perekonomian Indonesia dilanda krisis, diikuti oleh jatuhnya rezim orde baru. Dampaknya perekonomian saat itu mengalami kemunduran, bahkan terdapat sektor yang tumbuh dibawah $0 \%$. Hanya sektor pertanian, listrik, gas, dan air minum yang masih bertahan. Kondisi ini merupakan bukti bahwa Indonesia adalah negara agraris yang dapat bertahan hidup hingga sekarang ini. oleh karena itu pertanian masih menjadi sumber mata pencaharian 
bagi sebahagian besar masyarakat di Indonesia(Pasaribu,2012).

Produk pertanian pada umumnya dihasilkan sebagai bahan mentah yang mempunyai sifat mudah rusak dan tidak tahan lama, sehingga memerlukan adanya suatu proses pengolahan agar dapat meningkatkan nilai tambah melalui produk olahan dalam bentuk setengah jadi maupun barang jadi. Oleh karena itu, diperlukan industri pengolahan untuk mengelolah hasil pertanian tersebut.

Salah satu industri pengolahan yang berbahan baku produk pertanian adalah industri gula semut atau dikenal dengan nama palm sugar. Gula semut (palm sugar) merupakan jenis gula yang terbuat dari nira nipah yaitu cairan yang dihasilkan dari penyadapan tangkai bunga tanaman nipah. Keadaan alam Indonesia yang merupakan negara perairan sehingga tanaman nipah banyak tumbuh dan berkembang di Indonesia khususnya sepanjang daerah sungai atau pasang surut air laut. Oleh karena itu, banyak dijumpai masyarakat dan petani yang menyadap nira nipah sekaligus membuat gula semut di beberapa daerah yang memiliki hutan nipah, yang salah satunya adalah di Kelurahan pallantikang Kabupaten Takalar.

Kelurahan Pallantikang memiliki potensi sumber daya alam yang memadai salah satunya adalah tumbuh suburnya tanaman mangrove jenis nipah. Menurut Survei LSM MAP (2013),sekitar 7,34 ha tanaman nipah tumbuh di Kelurahan Pallantikang disepanjang pinggiran sungai yang jumlahnya kurang lebih 396 pohon.Tanaman nipah yang berumur 5 tahun keatas bisa disadap untuk mendapatkan nira. Nira merupakan cairan manis yang diperoleh dari tandan bunga yang belum mekar dengan melakukan proses penyadapan. Kadar air nira yang segar sebesar $80-85 \%$ dan sukrosa sekitar 15\%. Dalam proses penyadapan satu pohon nipah dapat menghasilkan sekitar $600 \mathrm{ml}$ nira. Menurut penelitian Sumarno (1997) bahwa satu pohon nipah dapat disadap hingga 50 tahun. Jadi, selama itu satu pohon nipah dapat menghasilkan 10.950 liter nira. Nira nipah memiliki kadar gula serta kandungan mineral yang tinggi sehingga nira nipah dapat dijadikan gula alternatif pengganti gula pasir untuk keperluan hidup seharihari dan sangat bagus untuk dikonsumsi bagi penderita diabetes.

Masyarakat

Kelurahan Pallantikang sudah sejak dulu menyadap nira nipah. Sekitar 30 orang aktif menyadap nira nipah di desa tersebut. Hasil sadapan terkadang dijadikan minuman beralkohol yang sering disebut minuman ballo.Minuman ini sering dikomsumsi langsung oleh penyadapnya bahkan diperjual belikan disekitar masyarakat Kelurahan Pallantikang dengan harga $35.000 /$ cergen. Padahal minuman ini dapat menimbulkan efek memabukkan dan merusak moral masyarakat. Akan tetapi ada salah satu keluarga di Kelurahan Pallantikanyangberinovasiuntuk mengembangkan nira nipah menjadi gula semut.

Industri gula semutyang berada di Kelurahan Pallantikang ini merupakan industri berskala rumah tangga, dimana penggunaan tenaga kerjanya adalah tenaga kerja keluarga dengan jumlah tenaga kerja kurang dari lima orang. Walaupun berskala industri rumah tangga, namun industri gula semut di Kabupaten Takalar khususnya di Kelurahan Pallantikang merupakan industri gula semut pertama yang memanfaatkan nira nipah. Kenyataan inilah yang mendorong peneliti untuk mengetahui lebih lanjut mengenai industri gula semut skala industri rumahan di 
Kelurahan Pallantikang kabupaten Takalardengan tujuan untuk mengetahui arus penyedian bahan baku nira nipah, produksi, tenaga kerja, pemasaran kelayakan finansial dan strategi pengembangan usaha industri rumahan gula semut di Kelurahan Pallantikang.

\section{KAJIAN LITERATUR}

Nipah (Nypa frutican) merupakan jenis palem yang tumbuh dilingkungan hutan bakau atau daerah pasang surut dekat tepi laut. Tanaman nipah memiliki peran penting dalam kehidupan ekologi sungai dimana rantai ekosistem sungai dapat terus terjaga dan terlindungi. (Heriyanto, dkk, 2011).

Setiap bagian tanaman nipah dapat dimanfaatkan salah satunya adalah tandan buah tanaman nipah yang menghasilkan nira nipah. Nira yang dihasilkan dari pohon nipah digunakan sebagai bahan bakupembuatan gula merah. Umumnya rata-rata produksi nira perhari satu tangkaibunga nipah mampu memproduksi sekitar 3 liter nira perhari dan setiap tangkaidapat dipanen terus menerus selama 20 hari. Rata-rata produksinira per malai 48-60 liter per pohon untuk jangka penyadapan selama 3 bulan. Berdasarkan analisis laboratorium, nira segar memiliki komposisi : Brix 15-17\%; Sukrosa 13-15 $\%$; Gula reduksi $0,2-0,5 \%$ dan abu 0,3$0,7 \%$ Oleh karena itu nira nipah ini sangat potensial untuk dijadikan gula merah ataupun gula pasir (Riyadi,2010) .

Menurut Heriyanto, Dkk (2011) Gula semut adalah gula merah berbentuk serbuk, beraroma khas, dan berwarna kuning kecoklatan. gula nipah cukup kaya karbohidrat dan unsur protein serta mineral lainnya. Secara lengkap, kadar zat gizi yang terkandung dalam gula nipah sebagai berikut :
Table 1. Kandungan Gizi Gula Nipah

\begin{tabular}{lllc}
\hline No. & Parameter & Satuan & Besaran \\
\hline 1. & Protein & $\% \mathrm{~W} / \mathrm{W}$ & 5,95 \\
2. & Kadar lemak & $\% \mathrm{~W} / \mathrm{W}$ & 0,23 \\
3. & Kadar air & $\% \mathrm{~W} / \mathrm{W}$ & 3,29 \\
4. & Karbohidrat & $\% \mathrm{~W} / \mathrm{W}$ & 89,61 \\
5. & Serat & $\% \mathrm{~W} / \mathrm{W}$ & 1,84 \\
6. & P & $\% \mathrm{~W} / \mathrm{W}$ & 1,33 \\
7. & $\mathrm{NaCl}$ & $\mathrm{mg} / \mathrm{kg}$ & $<2$ \\
8. & Ca & $\mathrm{mg} / \mathrm{kg}$ & 44,58 \\
9. & Fe & $\mathrm{mg} / \mathrm{kg}$ & $<0,05$ \\
10. & Kalori & $\mathrm{Cal} / \mathrm{gr}$ & 3172 \\
\hline
\end{tabular}

Menurut Kasmir dan Jakfar (2005)Studi kelayakan usaha adalah suatu kegiatan yang mempelajari secara mendalam tentang suatu kegiatan atau usaha yang akan dijalankan, dalam rangka menentukan layak atau tidak usaha tersebut dijalankan. Untuk menentukan layak atau tidaknya suatu usaha dapat dilihat dari berbagai aspek. Setiap aspek untuk dapat dikatakan layak harus memiliki suatu nilai standar tertentu. Aspek-aspek yang dinilai dalam studi kelayakan usaha meliputi legalitas usaha, Manajerial dan Administrasi, Teknis Produksi, Struktur Organisasi, Pemasaran, Keuangan (Finansial), Ekonomi, dan AMDAL (Analisis MengenaiDampak Lingkungan). Pada penelitian ini penulis hanya meneliti aspek keuangan atau finansial, untuk menentukan layak atau tidaknya usaha industri rumahan gula semut diKelurahan Pallantikang Kabupaten Takalar.Dimana 
pada aspek tersebut menggunakan kriteria uji, BCR (Net Cost Ration), NPV (Net Present Value), IRR (Interest Of Rate OF Return), BEP(Break Even Point), dan PBP (Pay Back Period)

Analisis SWOT (Strengths,

Weaknesses, Opportunities, Threats) adalah identifikasi berbagai factor secara otomatis untuk merumuskan strategi perusahaan atau UKM (Usaha Kecil dan Menengah). Analisis ini didasarkan pada logika yang dapat memaksimalkan kekuatan (strengths) dan peluang (opportunities), namun secara bersamaan dapat meminimilkan kelemahan (weaknesses) dan ancaman (threats). Proses pengambilan keputusan strategi selalu berkaitan dengan pengembangan misi, tujuan, strategi, dan kebijakan perusahaan. Dengan demikian perencana strategis harus menganalisis faktor-faktor strategis perusahaan (kekuatan, kelemahan, peluang, dan ancaman) dalam kondisi yang ada saat ini. Hal ini disebut dengan Analisis Situasi. Model yang paling popular untuk menganalisis situasi semacam ini adalah Analisis SWOT (Rangkuti. 2008).

Sebelumnya sudah ada penelitian mengenai analisis kelayakan usaha dan strategi pengembangan usaha akan tetapi objek yang diteliti berbeda yaitu usaha tempe. Menurut Mujiningsih,M. I., (2013) berdasarkan penelitian yang berjudul Analisis Kelayakan Usaha dan Strategi Pengembangan Industri Kecil Di Kecamatan Mateshi Kabupaten Karanganyar, menunjukkan bahwa industri kecil tempe di Kecamatan Matesih berjumlah 80 unit usaha dan mampu menyerap 53 orang tenaga kerja. Analisis Kelayakan NPV dari industri kecil tempe di Kecamatan Matesih Kabupaten Karanganyar layak dilakukan. Nilai BCR adalah sebesar 1,37, nilai IRR adalah sebesar $38,72 \%$. Analisis SWOT, Strategi yang dipakai adalah so (Strength Opportunities) yaitu mengatasi kelemahan-kelemahan yang ada dengan memanfaatkan peluang yang muncul. Rekomendasi yang diberikan dari penelitian ini adalah hendaknya generasi muda memperhatikan usaha tempe karena industri adalah industri yang layak dikembangkan dengan menjanjikan keuntungan yang besar. Penelitian ini hanya memperhitungkan analisis NPV, IRR dan nilai BCR (NetCostRation) untuk menentukan layak atau tidaknya Industri Kecil Di Kecamatan MateshiKabupaten Karanganyar tanpa menganalisis kriteria uji BEP.

\section{METODE PENELITIAN}

Penelitian dilaksanakan tanggal 16 April sampai 20 Mei 2015 di Kelurahan Pallantikang Kabupaten Takalar. Responden pada penelitian ini adalah salah satu industri rumahan gula semut yang ada di Kelurahan Pallantikang dan 30 orang petani penyadap nira nipah di kelurahan pallantikang. Tujuan dari pencarian data penyadap nira yaitu untuk mengetahui asal dari bahan pokok dan arus keberlanjutan penjualan nira nipah.

Penelitian ini dilaksanakan melalui beberapa tahapan. Pertama, pengumpulan data dengan cara wawancara langsung kepada pamilik usaha, para pekerja yang terlibat dalam proses pembuatan gula semut, petani penyadap nira nipah, Kantor Kelurahan Pallantikang, Badan Pusat Statistik, Dinas Perindustrian, Perdangangan, Koperasi dan UMKM, Dinas Kependudukan dan Pencatatan Sipil Kabupaten Takalar serta melakukan observasi di lokasi penelitian melalui pengamatan langsung mengenai nipah serta proses produksi gula semut dari nira nipah. Kedua, menganalisis hasil 
yang meliputi analisis kelayakan apek finansial berupa nilai $B C R, N P V$, IRR, BEP, dan PBP. Serta analisis SWOT dengan menggunakan Matriks IE dan Matriks SWOT untuk menentukan strategi pengembangan usaha industri rumahan gula semut.

\section{HASIL DAN PEMBAHASAN}

\section{Gambaran Umum Kelurahan Pallantikang}

Kelurahan Pallantikang berada dalam wilayah Kecamatan Pattallassang sebagai wilayah yang dekat dengan Ibu Kota Kabupaten dengan jarak 2,5 Km sedangkan jarak lbu Kota Provinsi Sulawesi Selatan $\pm 7 \mathrm{~km}$. Kelurahan pallantikang memiliki luas wilayah yaitu 299,47 ha. Kelurahan pallangtikang terdiri dari tujuh lingkungan, masing-masing Lingkungan Sandi, Manyampa, Limbungang, Bontopoko, Mattoanging, Pasuleang I, Pasuleang II. Data BPS menunjukkan bahwa tahun 2014 jumlah penduduk kelurahan Pallantikang mencapai 4397 orang. Berdasarkan sumber data dari LSM Magrove Action Project (2013) luas hutan nipah di Kelurahan Pallantikang sekitar 7,34 ha dengan jumlah pohon nipah 396 pohon. Di Kelurahan Pallantikang terdapat industri rumah tangga senyak 224 usaha dengan tenaga kerja 586 usaha dan industri kecil sebanyak 5 usaha dengan jumlah tenaga kerja 34 orang akan tetapi hanya ada 1 usaha industri rumahan gula semut yang terdapat di kelurahan Pallantikang.

\section{Karakteristik Responden Dikelurahan Pallantikang Kabupaten Takalar}

\section{Penyadap Nira Nipah Di Kelurahan Pallantikang}

Pendataan penyadap nira nipah bertujuan untuk mengetahui penyedian bahan baku dibagian hulu. Jumlah responden penyadap nira nipah di Kelurahan Pallantikang ini sebanyak 30 orang. Berdasarkan hasil penelitian diketahui bahwa kebanyakan penyadap nira nipah bejenis kelamin laki-laki sebanyak 27 orang, usia 31-40 tahun, dan tingkat pendidikan penyadap nira nipah kebanyakan hanya sampai tingkatan SD sebanyak 18 orang, hal ini disebabkan karena Pada profesi penyadapan nira nipah ini, tingkat pendidikan tidak terlalu berpengaruh terhadap proses penyadapan karena yang lebih dibutuhkan adalah pengalaman, baik yang diperoleh dari peyadap sendiri maupun dari orang lain.

Penyadap nira nipah terbagi ditiap Lingkungan di Kelurahan Pallantikang. Hal ini dikarenakan Kelurahan Pallantikang merupakan daerah yang dilalui beberapa sungai dan memiliki daerah tambak yang luas, sehingga sangat banyak tumbuh tanaman nipah di daerah tersebut. Masyarakat yang memiliki tanaman nipah memanfaatkan nira nipah untuk disadap. Adapun data sebaran responden penyadap nira nipah yang ada di tiap Lingkungan Kelurahan Pallantikang yaitu, di lingkungan pasuleang 1 sebanyak 3 orang, Lingkungan Pasuleang 2 sebanyak 18 orang, Lingkungan Bontoppoko Sebanyak 18 orang dan Lingkungan Mattoanging sebanyak 4 orang. 


\section{Pengolah Gula Semut di Kelurahan Pallantikang}

Pada tahun 2013, Lembaga

Sosial Masyarakat Mangrove Action Project (LSM MAP) bekerjasama dengan pemerintah setempat untuk melakukan pelatihan pembuatan gula semut di lingkungan pasuleang 1 dan 2. Selama pelatihan tersebut terlaksana, ada beberapa warga yang dapat membuat gula semut dari nira nipah, akan tetapi hanya ada satu usaha yang dapat bertahan hingga saat ini yaitu usaha Nipah Lestari Takalar yang di ketua oleh bapak Daeng Nai dengan status kepemilikian usaha adalah milik sendiri. Jumlah tenaga kerja usaha gula semut ini sekitar 4 orang tenaga kerja tetap dan 2 orang tenaga kerja tidak tetap yang berasal dari anggota keluarga sendiri dan ibu rumah tangga tinggal di sekitar tempat usaha. Sistem pembayaran upah diberikan setiap bulannya. Bahan baku nira nipah di peroleh dari penyadap dan untuk bahan baku lainnya dibeli di Pasar Umum Pattallassang. Teknologi yang digunakan pada usaha ini masih bersifat tradisional sehingga hanya sedikit produksi gula semut yang dihasilkan. Ada beberapa varian rasa yang dibuat diantaranya gula kelapa, gula merah, gula nipah rasa temulawak dan gula nipah rasa jahe. Pemasaran prodak belum meluas dikarenakan belum adanya izin Depkes dan BPOM sehingga prodak belum dapat diterima di beberapa toko swalayan.

\section{Kondisi penyadap Nira dan Pengolahan Gula Semut di Kelurahan Pallantikang}

\section{Penyadap atau Pengolah Nipah di Kelurahan Pallatikang}

Berdasarkan hasil wawancara diketahui bahwa jumlah pohon nipah yang disadap sekitar 1-10 pohon dengan status kepemilikan lahan milik orang lain. Adapun proses penyadapan nira mulai : (1) pemilihan pohon nipah yang siap disadap dengan 81ompetit pohon nipah berumur 5 tahun dan memiliki 2 atau 3 tandan bunga yang muncul.(2) pemukulan tangkai bunga yang bertujuan untuk memperbesar pori-pori dan melunakkan tandan bunga jantan, sehingga nira mudah keluar. (3) dilakukan pengirisan pada ujung tangkai bunga yang yang telah dipukul terlebih dahulu setelah itu dilakukan penyadapan. Penyadapan tangkai bunga ini terus menghasilkan nira sampai kurang lebih 30 hari. Dalam wadah 81ompeti tempat penyadapan nira diberi laru yaitu suatu campuran yang terdiri atas kapur sirih, penggunaan laru dimaksudkan agar nira tidak masam karena kapur sirih berfungsi untuk menghambat fermentasi nira yang disebabkan oleh mikroorganisme. Penadahan dilakukan 2 kali pagi dan sore hari, waktu penadahan nira yang diambil pada pagi hari yaitu sekitar pukul 16.00 sore sampai 06.00 pagi, sedangkan waktu penadahan nira yang diambil pada sore hari yaitu sekitar pukul 06.00 pagi sampai 16.00 sore.

Hasil sadapan yang diperoleh sekitar 1-5 liter perhari dimana hasil sadapan nira untuk dijadikan gula sebanyak 9 orang dan selebihnya dijadikan minuman beralkohol atau ballo sebanyak 21 orang hal ini disebabkan karena kurangnya pengusaha yang mengelolah nira nipah menjadi gula semut sehingga banyak penyadap yang masih menjual niranya sebagai minuman ballo. Pada proses penyadapan nira nipah yang di hasilkan adalah nira murni akan tetapi jika ada pesanan dari konsumen maka dijual nira beralkohol, dengan menanbahkan potongan kayu atau sering disebut proses sene yang 
dapat menyebabkan terjadinya fermentasi pada nira nipah sehingga menghasilkan 82ompeti.

Harga nira nipah yang dijualkan perliternya bervariasi, mulai dari harga Rp. 7.500 hingga Rp. 8.000 , tetapi harga nira yang murni lebih tinggi di bandingkan nira beralkohol. Hal ini disebabkan proses penyadapan nira murni sangat di butuhkan kehati-hatian karena nira sangat cepat mengalami proses fermantasi yang mengakibatkan rasa masam dan pahit pada nira.

Penyadap nira nipah yang berkeinginan untuk memproduksi gula semut dari hasil sadapannya sekiar 18 orang selebihnya hanya ingin menjual nira nipah sebagai minuman murni dan ballo.

\section{Pengolahan Nira Menjadi Gula Semut di Kelurahan Pallantikang}

Berdasarkan hasil pengamatan dan wawancara diketahui bahwa usaha yang dijalankan oleh produsen gula semut di Kelurahan Pallantikang ini masih sangat sederhana, hal ini terlihat kegiatan pengolahan serta alat pengolahan yang digunakan masih tradisional. Adapun proses pengolahan gula semut di Kelurahan Pallantikang yaitu Nira yang telah diperoleh dari hasil sadapan disaring terlebih dahulu agar terbebas dari kotoran. Penyaringan dilakukan 2 kali dengan menggunakan penyaring yang terbuat dari kawat halus dan nilon. Nira yang akan diolah sebanyak 5 liter. Nira hasil saringan secepatnya dimasukkan dalam wajan/82ompe kemudian dipanaskan sampai $110^{\circ} \mathrm{C}$ sambil dilakukan pengadukan. Dalam proses pemasakan ini, saat mendidih kotoran halus akan mengapung bersama busa nira. Tambahkan santan kental $300 \mathrm{ml}$ serta $50 \mathrm{~g}$ gula untuk mempermudah proses pengkristalan gula semut. jika ingin membuat varian rasa jahe atau temulawak maka tambahkan jahe atau temulawak yang telah di ambil sarinya sebanyak $50 \mathrm{ml}$. Bila nira sudah pekat dan mulai berubah warna berarti nira sudah masak. Lama proses pemasakan nira sekitar 1,5 jam. Nira yang sudah masak diangkat dari tungku dan tetap dilakukan pengadukan hingga pekatan nira mulai mendingin dan membentuk butiran-butiran 82ompeti gula. Setelah terbentuk butiran 82ompeti gula maka gunakan tempurung kelapa untuk menghamburkan gumpalan 82ompeti gula. Gunakan saringan gula semut agar hasil butiran 82ompeti gula memiliki ukuran yang sama. Keringkan gula dibawah sinar matahari hingga kering. Gula semut kering yang dihasilkan dari proses pemasakan berkisar antara 2-3 $\mathrm{kg}$. Pada industri gula semut di Kelurahan Pallantikang per hari dapat memproduksi gula semut sebanyak $10-15 \mathrm{~kg}$. setelah gula semut selesai dikeringkan maka proses selanjutnya adalah pengemasan. Gula semut dimasukkan kedalam kemasan aluminium foil dengan berat 1 $\mathrm{kg}$ dan diberi label.

Industri rumahan gula semut di kelurahan Pallantikang memiliki beberapa jenis varian rasa pada produknya, diantaranya Gula Kelapa, Gula Merah, Gula Nipah Rasa Jahe dan Gula Nipah Rasa Temulawak. Harga perkemasannya sekitar Rp. 25. 000.

Berdasarkan wawancara dengan pemilik usaha gula semut, proses produksi usaha ini menggunakan tenaga kerja tetap yang berjumlah 4 orang dan 2 orang tenaga kerja tidak tetap. Pembagian kerja pada proses produksi gula semut dilakukan sesuai dengan tugas masing-masing yaitu satu orang yang menangani input bahan, dua orang dalam proses pemasakan gula, dan satu orang yang menangani output hingga 
pemasaran produksi dengan biaya upah tenaga kerja perhari sekitar Rp. 16.000 perorang.

\section{Faktor-faktor Mendukung Pengembangan dari Usaha Industri Rumahan Gula Semut Di Kelurahan Pallantikang}

Informasi yang diperoleh dari
hasil wawancara dan pengamatan
langsung di Kelurahan Pallantikang
diperoleh beberapa faktor-faktor yang
berpengaruh pada pengembangan
industri rumahan gula semut di Kelurahan
Pallantikang yaitu di lokasi usaha sangat
tersedia tenaga kerja yang memadai
karena letak industri gula semut ini
berada pada daerah yang padat
penduduk, dimana sebahagian besar
mata pencaharian penduduk adalah
petani dan ibu rumah tangga yang dapat
direkrut untuk dijadikan tenaga kerja baik
sebagai pengolah gula maupun penyadap
nira. Tersediaanya bahan baku yang
memadai karena bahan baku gula
tumbuh subur di daerah industri seperti
pohon nipah, sehingga kualitas niranya
terjaga. Produk yang dihasilkan memiliki
banyak varian rasa dan berkhasiat untuk
kesehatan karena bahan bakunya berasal
dari tumbuhan obat-obatan.
Adanya dukungan dan perhatian
pemeritah melalui Dinas Perindustrian,
Koperasi, perdagangan dan UMKM
dengan melakukan kerjasama baik
pemberian modal usaha ataupun
pelatihan untuk pengusaha gula semut.
selain itu kurangnya 83ompetitor di
daerah Takalar dan lokasi usaha dekat
dengan pusat pemasaran baik di pasar
kabupaten maupun ibukota Provinsi.
Kebutuhan gula di masyarakat
sebagai alternative untuk penderita
diabetes terus mengalami meningkat
sehingga prodak ini sangat cocok karena

gula semut dari nira nipah mengandung mineral yang tinggi sehingga sangat bagus untuk dikomsumsi bagi penderita diabetes. Selain itu prodak ini dapat menjadi subsitusi gula tebu karena harga gula tebu saringkali meningkat sehingga di butuhkangula alternative pengganti gula tebu.

\section{Faktor-Faktor yang Menghambat Pengembangan dari Usaha Industri Rumahan Gula Semut di Kelurahan Pallantikang}

Hasil wawancara dan pengamatan di lokasi penelitian ini diproleh beberapa faktor yang menghambat pengembagangan dari usaha industri rumahan gula semut di Kelurahan Pallantikang yaitu, dana investasi, modal kerja terbatas serta peralatan yang digunakan pada proses produksi sangat tradisional sehingga menyebabkan kurang maksimal dalam proses produksi. Belum adanya izin Depkes dan BPOM sehingga menyebabkan distribusi gula semut belum meluas di luar Kabupaten khususnya di toko swalayan. Pemilik usaha kurang professional dalam manajemen keuangan sehingga pengolahan keuangan kurang terkoordinir dengan baik. Selain itu harga produk tinggi yang menyebabkan kurangnya daya tarik konsumen untuk membeli prodak gula semut ini.

Pengembangan usaha gula semut juga terhambat akibat bahan baku nira dijadikan ballo karena masih banyaknya warga yang menyadap nira untuk dijadikan ballo. Selain itu jumlah pengrajin gula semut terbatas dan cuaca kurang mendukung sehingga dapat menghambat proses produksi. Hal yang terpenting adalah saingan produk dari daerah luar yang memiliki kualitas yang lebih baik seperti produk dari Jawa yang 
dijual dipasaran yang dapat menjadi 84ompetitor di pasaran.

\section{Hal-Hal yang Dibutuhkan oleh Penyadap Dan Pengusaha Gula Semut di Kelurahan Pallantikang}

Hasil wawancara yang dilakukan kepada penyadap nira dan pengusaha gula semut selama penelitian, diketahui bahwa ada beberapa hal yang dibutuhkan penyadap dan pengusaha gula semut diantaranya sebagai berikut :

a. Penyadap nira nipah membutuhkan pelatihan pembuatan gula semut karena sebahagian besar penyadap tidak mengetahui proses pembuatan gula semut.

b. Pengusaha gula semut membutuhkan peralatan yang berbasisi teknologi seperti mesin pembuatan gula semut karena selama proses produksi industri ini masih menggunakan peralatan tradisional yang menyebabkan terhambatnya proses produksi. Selain itu industri ini membutuhkan alat pengering agar tidak tergantung lagi pada sinar matahari yang setiap saat dapat berubah-ubah.

c. Pengusaha gula semut membutuhkan pelatihan terkait manajemen keuangan karena selama usaha ini berdiri pengolahan keuangan kurang terkoordinir dengan baik.

\section{Analisis Strategi Pengembangan Usaha}

\section{Analisis Strategi Internal (IFAS)}

Dengan menggunakan analisis internal, posisi industri kerajinan gula semut di Kelurahan Pallantikang adalah sebagai berikut :
Faktor internal kekuatan pada industri kerajinan gula semut di Kelurahan Pallantikang memiliki skor 0,15 pada 84ompetito tersediannya tenaga kerja yang memadai karena banyak warga sekitar industri yang direkrut untuk dijadikan tenaga kerja baik di pabrik atau menyadap nira. Tersediannya bahan baku yang memadai memiliki skor 0,8, dikarenakan bahan baku gula tumbuh subur di daerah industri seperti pohon nipah, sehingga kualitas niranya terjaga. Banyaknya varian rasa yang prodak yang hasilkan memiliki skor 0,4, agar konsumen dapat memilih sesuai dengan keinginan. Produk yang dihasilkan berkhasiat untuk kesehatan memiliki skor 0,4 . Karena bahan baku berasal dari tumbuhan obat-obatan sehingga sangat baik untuk kesehatan. Dan tersediannya media promosi pada label kemasan memilikin skor 0,2 karena memberikan informasi produk kepada konsumen.

Faktor internal kelemahan pada industri kerajinan gula semut di Kelurahan Pallantikang memiliki skor 0,3 pada 84ompetito teknologi produksi sederhana sehingga menyebabkan kurang maksimal dalam proses produksi. Dana investasi dan modal kerja terbatas memiliki skor 0,1 , karena kurangnya dana dan modal sehingga proses produksi terkadang berhenti, Distribusi gula semut belum meluas di luar Kabupaten memiliki skor 0,05 , karena belum adanya izin BPOM dan kurangnya promosi sehingga produk belum dipasarkan diluar Kabupaten. Belum adanya izin badan BPOM memiliki skor 0,2, untuk perizinan BPOM sementara dalam proses pengurusan. Kurang 84ompetitor8484 dalam manajemen keuangan memiliki skor 0,05, karena selama usaha ini berdiri pengolahan keuangan kurang terkoordinir dengan baik. Selain itu harga produk tinggi memiliki skor 0,05 . Karena 
kurangnya daya tarik konsumen untuk membeli karena harga produk tinggi

Data tersebut diatas memperlihatkan bahwa total skor faktor internal mencapai 2,65. Hal ini berarti industri rumahan gula semut di Kelurahan Pallantikang mengindikasikan posisi internal yang kuat, berdasarkan David (2009) skor bobot total dibawah 2,5 mencirikan organisasi yang lemah secara internal sedangkan skor yang secara siknifikan berada diatas 2,5 menandakan posisi internal yang kuat.

\section{Analisis Strategi Eksternal (EFAS)}

Dengan menggunakan analisis eksternal, posisi industri kerajinan gula semut di Kelurahan Pallantikang adalah sebagai berikut :

faktor eksternal peluang pada industri rumahan gula semut di Kelurahan Pallatikang memiliki skor 0,3 pada 85ompetito dukungan dan perhatian pemerintah karena dapat bekerjasama dengan Dinas Koperasi, perdagangan, industri dan UMKM. Kurangnya 85ompetitor di daerah Takalar memiliki skor 0,4, karena pengusaha Nipah Lestari Sejahtera yang berhasil mengembangkan nira nipah menjadi gula semut. Sentra pasar memiliki skor 0,4, dekat dengan pasar umum kabupaten serta ibu kota provinsi sebagai pusat pemasaran. Kebutuhan gula 85ompetitor85 untuk penderita diabetes terus meningkat memiliki skor 0,6 , karena gula semut dari nira nipah mengandung mineral yang tinggi sehingga sangat bagus untuk dikomsumsi penderita diabetes. Serta produk subsitusi gula tebu memiliki skor 0,1 karena sebagai 85ompetitor85 pengganti gula tebu.

Faktor eksternal ancaman pada industri rumahan gula semut di Kelurahan Pallantikang memiliki skor 0,3 pada 85ompetito bahan baku nira dijadikan ballo memiliki, karena masih banyaknya warga yang menyadap nira untuk dijadikan tuak atau ballo. Jumlah pengrajin gula semut terbatas memiliki skor 0,1, karena ditakutkan kurangnya tenaga kerja yang memiliki keahlian membuat gula semut sehingga dapat mempengaruhi produksi industri. Cuaca kurang mendukung memiliki skor 0,1, karena dapat menghambat proses produksi dalam hal ini proses penjemuran. Serta saingan produk dari daerah luar memiliki skor 0,15, karena banyak produk dari jawa yang dijual dipasaran sehingga dapat menjadi 85ompetitor di pasaran.

Data tersebut diatas memperlihatkan bahwa total skor faktor eksternal mencapai 2,45. Hal ini berarti industri rumahan gula semut di Kelurahan Pallantikang mengindikasikan masih cukup lemah secara eksternal.

\section{Matriks Internal dan Eksternal (Matriks IE)}

Hasil analisis kekuatan, kelemahan, peluang, dan ancaman dari industri rumahan gula semut di Kelurahan Pallantikang diperoleh matrik internal dan eksternal (Matriks IE) sebagai berikut:

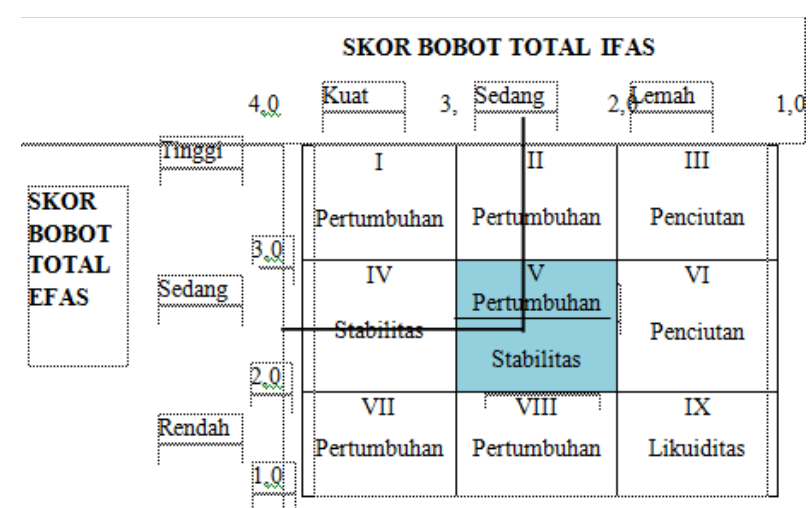

Gambar 1. Matriks Internal Eksternal (IE) 


\begin{abstract}
Rata-rata matriks internal memiliki skor 2,65 dan eksternal menujukkan pada 2,45. Hal ini berarti industri rumahan gula semut di Kelurahan Pallantikang berada pada posisi V dengan strategi konsentrasi melalui integritas horizontal atau stabilitas (tidak ada perubahan dalam pendapatan), dimaksudkan usaha yang berada di sel ini dapat memperluas pasar, fasilitas produksi dan teknologi melalui perkembangan internal dan eksternal. Strategi yang dapat diterapkan, yaitu menghindari kehilangan penjualan dan kehilangan profit.

Kenyataan menunjukkan bahwa industri rumahan gula semut di Kelurahan Pallantikang berada pada tahap stabil dan tidak mengalami pertumbuhan. Hal ini diperkuat dengan kondisi peralatan yang digunakan pada proses pembuatan gula semut masih sangat tradisional serta belum adanya izin Depkes dan BPOM untuk prodak, sehingga mempengaruhi proses penjualan dan pemasaran.
\end{abstract}

\section{Analisis SWOT}

Penentuan strategi yang sesuai bagi pengembangan usa industri rumahan gula semut di Kelurahan Pallantikang adalah dengan cara membuat matriks SWOT. Matrik SWOT ini dibangun berdasarkan faktor-faktor eksternal mauoun internal yang terdiri dari peluang, ancaman, kekutana, dan kelemahan.

Berdasarkan matriks SWOT maka dapat disusun empat strategi utama yaitu SO, WO, ST, dan WT. Strategi bagi pengembangan usaha industri rumahan gula semut dapat dilihat pada Tabel 1.
Tabel 1. Hasil Analisis SWOT

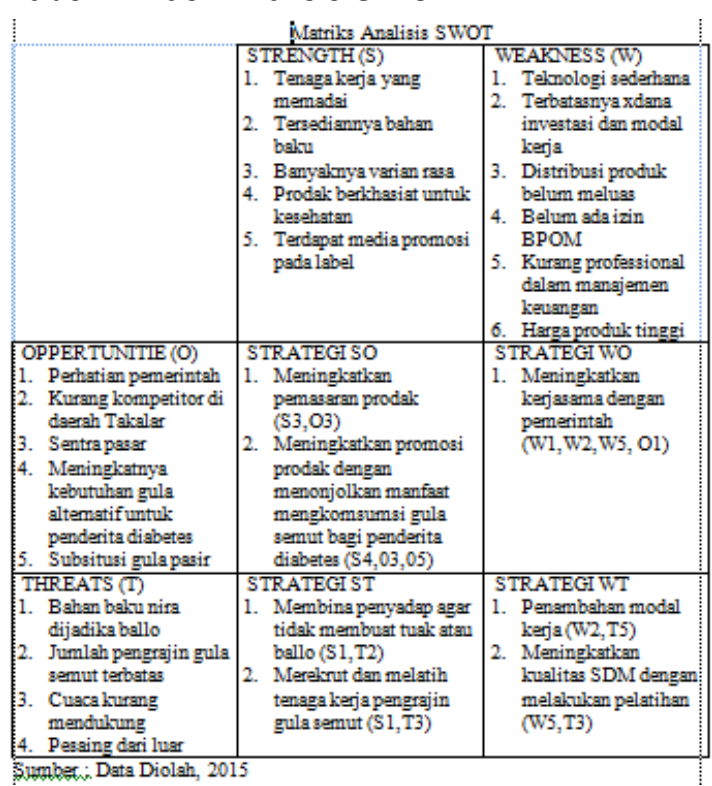

\section{Strategi 'SO (Strength-Opportunity)'}

Strategi pengembangan usaha industri rumahan gula semut di Kelurahan Pallantikang dengan menggunakan seluruh kekuatan untuk memanfaatkan peluang yang ada, yaitu :

a. Meningkatkan pemasaran prodak (S3,O3)Bertujuan untuk meningkatkan pendapatan usaha dengan memasarkan produk yang dihasilkan dan didukung oleh ketersediaan pasar umum yang ada di Kelurahan Pallantikang dan kabupaten Takalar

b. Meningkatkan promosi produk dengan menonjolkan manfaat mengkomsumsi gula semut bagi penderita (S4,03,05)Bertujuan untuk memperkenalkan produk yang dihasilkan di pasaran dengan menonjolkan manfaat dan khasiat produk yang didukung olah masalah atau isu yang dihadapi masyarakat seperti subsitusi pengganti gula semut dan meningkatnya kebutuhan gula alternatif untuk penderita 
diabetes, sehingga memungkinkan untuk meningkatkanproduksi produk agar mampu menjangkau pasar yang lebih luas.

\section{Strategi 'WO (Weakness-Oppertunity) Strategi pengembangan usaha industri rumahan gula semut di Kelurahan Pallantikang dapat meminimalkan kelemahan untuk memanfaatkan peluang yang ada yaitu meningkatkan kerjasama dengan pemerintah (W1,W2,W5,01), meningkatkan kerjasama dengan pemerintah dan pengusaha gula semut, maka pengusaha dapat diberikan bantuan modal usaha, peralatan atau teknologi moderen, dan pelatihan bagi pemilik usaha dan pengrajin gula semut.}

\section{Strategi 'ST (Strength-Oppertunity)'}

Strategi pengembangan usaha industri rumahan gula semut di Kelurahan Pallantikang dapat mengatasi ancaman yang ada dengan menggunakan seluruh kekuatan, diantaranya sebagai berikut:

a. Membina pengrajin gula semut agar tidak membuat tuak atau ballo $(\mathrm{S} 1, \mathrm{~T} 2)$. Tujuannya agar bahan baku nira murni dapat terus tersedia secara kontinyu dan meminimalkan nira menjadi ballo, maka diperlukan pembinaan bagi warga penyadap maupun warga sekitar Kelurahan Pallantikang.

b. Merekrut dan melatih tenaga kerja pengrajin gula semut $(\mathrm{S} 1, \mathrm{~T} 2)$. Tujuan untuk menambah jumlah tenaga kerja pengrajin gula semut dengan kata lain diperlukan perekrutan tenaga kerja yang ada di Kelurahan Pallantikang agar induatri dapat terus berproduksi.

\section{Strategi 'WT (Weakness-Treaths)'}

Strategi pengembangan usaha industri rumahan gula semut di Kelurahan Pallantikang dengan meminimalkan kelemahan dan menghindari ancaman yaitu :

a. Menambah modal kerja (W2,T5). Dengan adanya penambahan modal kerja maka produksi dapat ditingkatkan kualitas dan kuantitasnya agar dapat bersaing dengan produk dari luar.

b. Meningkatkan kualitas SDM dengan melakukan pelatihan (W5,T3). Diperlukannya pelatihan SDM baik pemilik usaha dan tenaga kerja terkait dengan manajemen keuangan dan pelatihan pembuatan gula semut sehingga pemilik usaha dan tenaga kerja dapat menjalankan industri rumahan gula semut dengan baik dan benar.

Berdasarkan strategi matriks SWOT maka dapat diketahui strategi yang sangat dibutuhkan untuk dapat meminimalisir kelemahan dan ancaman yang dihadapi, yaitu

1. Meningkatkan pendapatan usaha dengan memasarkan produk yang bermutu dan didukung oleh ketersediaan pasar baik di Kelurahan maupun Kabupaten.

2. Menjalin kerjasama dengan pemerintah Kabupaten Takalar untuk mendapatkan bantuan baik berupa modal usaha, peralatan, maupun pelatihan bagi pemilik usaha dan para pekerja pengrajin gula semut.

3. Melakukan pelatihan dan pembinaan kepada penyadap nira terkait pengolahan nira nipah agat tidak membuat ballo atau minuman beralkohol agar dapat menjaga keberlanjutan produksi gula. 


\section{Perhitungan Analisis Kelayakan Usaha Industri Rumahan Gula Semut Di Kelurahan Pallantikang}

Untuk mengetahui posisi keuangan dari usaha industri rumahan gula semut di Kelurahan Pallantikang, perlu dilakukan suatu perhitungan analisis kelayakan dengan menentukan nilai investasi usaha, biaya, penerimaan, BCR, NPV, IRR, BEP, dan PBP agar usaha tersebut dapat ditentukan layak atau tidaknya untuk dijalankan. Akan tetapi sebelum melakukan perhitungan analisis kelayakan, maka terlebih dahulu harus ditentukan asumsi atau parameter teknis yang digunakan. Asumsi dan parameter untuk analisis keuangan industri rumahan gula semut menjelaskan gambaran umun variable-variabel yang digunakan dalam perhitungan analisis keuangan. Asumsi tersebut diambil berdasarkan survei lapangan yang dilakukan terhadap industri rumahan gula semut di Kelurahan Pallantikang. Untuk memudahkan melakukan analisis, beberapa asumsi yang digunakan adalah sebagai berikut :

1. Umur industri diasumsikan selama 5 tahun.

2. Jumlah hari kerja selama 25 hari kerja setiap bulannya dan selama 12 bulan setiap tahunnya.

3. Penentuan data penerimaan berdasarkan data harga yang berlaku pada saat dilakukan penelitian dan diasumsikan konstan selama 5 tahun. Hal ini dikarenakan tidak adanya catatan pembukuan pengeluaran dan pemasukan pada usaha ini.

4. Data biaya investasi berdasarkan pada awal berdirinya usaha.

5. Discount Factor yang digunakan merupakan suku bunga Bank BRI pada saat dilakukan penelitian yaitu Bulan April 2015 sebesar $15 \%$.

6. Nilai inflasi Kabuaten Takalar tahun 2013 sebesar 3,03\%, 2014 sebesar $1,23 \%$ dan tahun $2015-2017$ sebesar 0,73 .

7. Pajak penghasilan yang digunakan sebesar $1 \%$.

Adapun perhitungannya nilai investasi usaha, biaya, penerimaan, BCR, NPV, IRR, BEP, dan PBP sebagai berikut:

\section{A. Investasi Usaha}

Biaya investasi adalah biaya tetap yang besarnya tidak dipengaruhi oleh jumlah produk yang dihasilkan. Investasi yang dibutuhkan untuk usaha industri rumahan gula semut sebesar Rp. 27.616.000. terdiri dari invesyasi biaya pengadaan bangunan, dan alat pengolahan produk. Seperti : wajan, panic, kompor, pengaduk kayu, paengaduk gula, alat penyaring gula, timbangan manual, timbangan elektrik, mesin pengepres, dan penyaring kecil. 
Tabel 2. Biaya Investasi Industri Rumahan Gula Semut di Kelurahan Pallantikang

\begin{tabular}{rlrrrr}
\hline \multicolumn{1}{c}{} & \multicolumn{1}{c}{ Tahun $\mathbf{2 0 1 5}$} & & \\
No & \multicolumn{1}{c}{ Uumlah } & Unit & Harga (Rp) & Biaya (Rp) \\
\hline 1 & Biaya Pengadaan Bangunan & 1 & Unit & 23.000 .000 & 25.000 .000 \\
2 & Wajan & 4 & Unit & 200.000 .000 & 800.000 .000 \\
3 & Panci & 6 & Unit & 15.000 & 90.000 \\
4 & Kompor & 2 & Unit & 150.000 & 300.000 \\
5 & Pengaduk Kayu & 4 & Unit & 5.000 & 20.000 \\
6 & Pengaduk Gula & 4 & Unit & 5.000 & 20.000 \\
7 & Alat Penyaring Gula & 8 & Unit & 100.000 & 800.000 \\
8 & Timbangan Manual & 1 & Unit & 40.000 & 40.000 \\
9 & Timbangan Elektrik & 2 & Unit & 120.000 & 120.000 \\
10 & Mesin Pengepres & 1 & Unit & 300.000 & 300.000 \\
11 & PenvarinaKecil & 2 & Unit & 3.000 & 6.000 \\
\hline & & & & & 27.616 .000
\end{tabular}

\section{B. Biaya}

Biaya adalah nilai pengeluaran yang dikeluarkan dalam proses produksi. Biaya dalam hal ini adalah keseluruhan biaya yang dikeluarkan untuk proses pembuatan gula semut sampai pemasaran produk, yang terdiri dari biaya tetap dan biaya variable.

\section{Biaya Tetap}

Biaya tetap adalah biaya yang digunakan dalam industri gula semut skala rumah tangga di Kelurahan Pallantikang yang besarnya tidak dipengaruhi oleh jumlah gula semut yang dihasilkan. Biaya yang dibutuhkan untuk usaha industri rumahan gula semut sebesar Rp. 16.250.000. terdiri dari biaya gaji tenaga kerja, pajak bangunan, biaya perawatan dan perlengkapan produksi, biaya perawan alat transportasi. Adapun biaya tetap dapat dilaihat pada Tabel 3 sebagai berikut:

Tabel 3.Biaya Tetap Produksi Gula Semut di Kelurahan Pallantikang Tahun 2015

\begin{tabular}{rlccrrr}
\hline No & \multicolumn{1}{c}{ Uraian } & Jumlah & Unit & $\begin{array}{c}\text { Harga } \\
\text { (Rp) }\end{array}$ & Unit & \multicolumn{1}{c}{$\begin{array}{c}\text { Biaya (Rp) } \\
\text { Pertahun }\end{array}$} \\
\hline 1 & Gaji Tenaga KerjaTetap & 4 & orang & 300.000 & Perbulan & 14.400 .000 \\
2 & $\begin{array}{l}\text { Pajak Bangunan } \\
3\end{array}$ & 1 & Rumah & 50.000 & Pertahun & 50.000 \\
& $\begin{array}{l}\text { Biaya Perawatan dan } \\
\text { Perlengkapan Produksi }\end{array}$ & & & 100.000 & Perbulan & 1.200 .000 \\
4 & $\begin{array}{l}\text { Biaya Perawatan Alat } \\
\text { Transnortasi }\end{array}$ & & 50.000 & Perbulan & 600.000 \\
\hline & & & Total & & 16.250 .000
\end{tabular}

\section{BiayaVariabel}

Biaya variabel adalah biaya yang digunakan dalam industri rumahan gula semut di Kelurahan Pallatikang yang besarnya berubah-ubah secara proporsional sesuai dengan jumlah gula 
semut yang dihasilkan. Biaya variable yang di keluarkan industri rumahan gula semut dalam waktu satu tahun sebesar
Rp. 40.743.000. Adapun biaya variabel pada industri rumahan gula semut dapat dilihat pada Tabel 4 . sebagai berikut :

Tabel. 4. Biaya Variabel Produksi Gula Semut di Kelurahan Pallantikang Tahun 2015

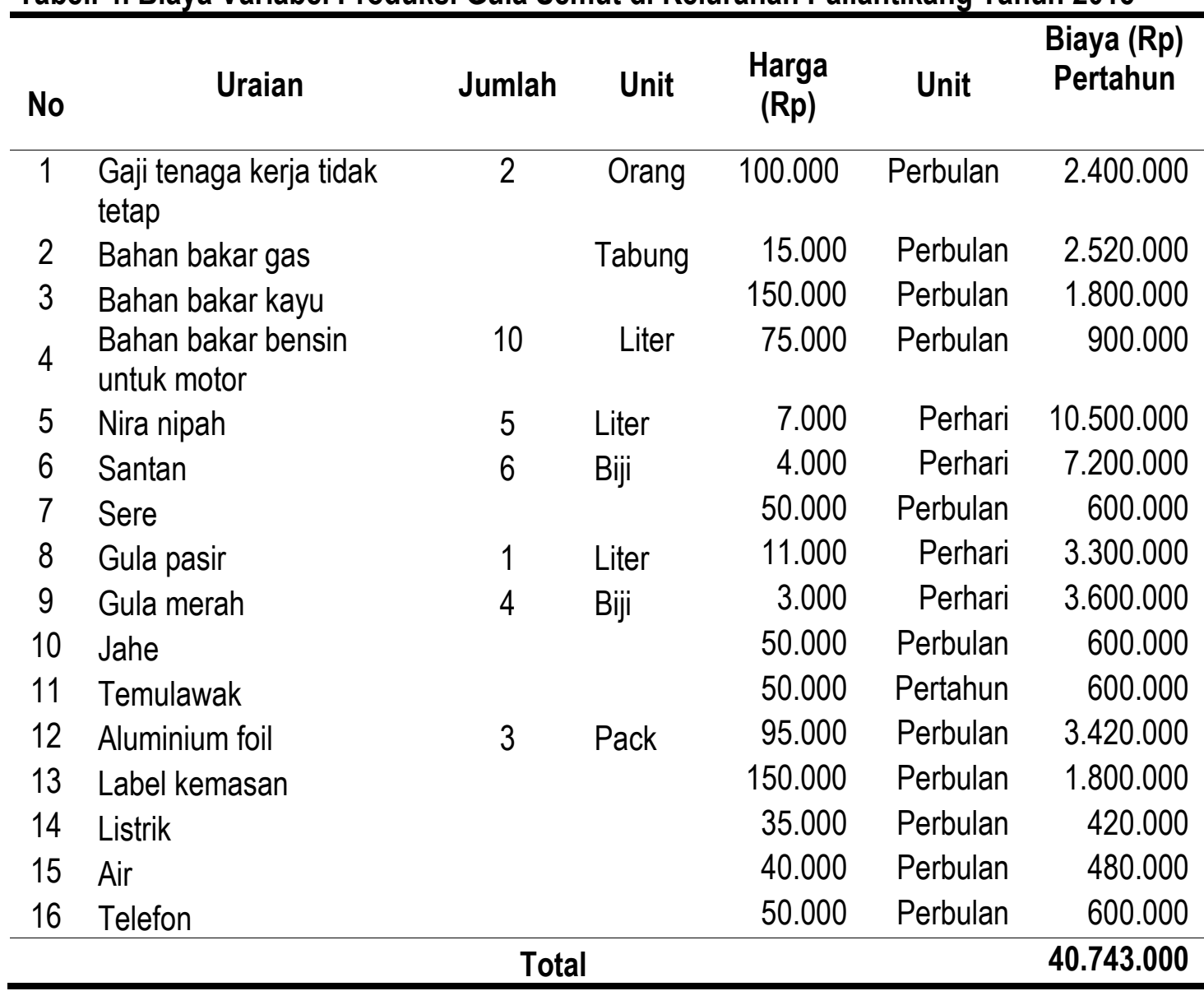

\section{Total Biaya}

Biaya total dalam industri gula semut di Kelurahan Pallantikang merupakan hasil dari penjumlahan seluruh biaya tetap dan biaya variabel yang dikeluarkan selama proses produksi gula semut. Adapun total biaya pengolahan gula semut dapat dilihat pada Tabel 5.
Tabel 5. Biaya total

\begin{tabular}{lcc}
\hline No & $\begin{array}{c}\text { Jenis Biaya } \\
\text { Total }\end{array}$ & Biaya (Rp) \\
\hline 1 & Biaya Tetap & 16.250 .000 \\
2 & Biaya \\
& Variabel \\
\hline & Total \\
\hline 4. & $\begin{array}{c}\text { Pendapatan Tiap Tahun } \\
\text { Industri rumahan gula semut di }\end{array}$ \\
Kelurahan Pallantikang memiliki \\
beberapa jenis varian rasa pada
\end{tabular}


produknya, diantaranya Gula Kelapa, Gula Merah, Gula Nipah Rasa Jahe dan Gula Nipah Rasa Temulawak. Perharinya usaha ini menghasilkan 10 bungkus untuk varian rasa gula kelapa dan gula merah sedangkan 11 bungkus untuk varian rasa temulawak dan jahe.

Perharinya industri ini hanya memproduksi 1 varian rasa. Harga perkemasan tiap produk sama yaitu Rp. 25.000 dan jumlah produk yang dihasilkan perbulannya 252 jika dikalikan 12 bulan menghasilkan 3.624 unit sehingga pendapatan pertahunnya diperoleh Rp. 75.600.000. adapun total pendapatan dapat dilihat pada Tabel 6 .

Tabel 6. Total Pendapatan

\begin{tabular}{llcrrr}
\hline No & Uraian & $\begin{array}{c}\text { Penjualan } \\
\text { Produk / bulan }\end{array}$ & Harga & Nilai/Bulan & Nilai/Tahun \\
\hline 1 & Gula Kelapa & 60 & 25.000 & 100.000 & 2.400 .000 \\
2 & Gula Merah & 60 & 25.000 & 12.000 & 816.000 \\
3 & Gula nipah rasa jahe & 66 & 25.000 & 150.000 & 1.800 .000 \\
4 & Gula nipah rasa temulawak & 66 & 25.000 & 75.000 & 900.000 \\
5 & Nira nipah & 66 & & 7.000 & 10.500 .000 \\
& Total & $\mathbf{2 5 2}$ & & \\
\hline
\end{tabular}

\section{Benefit Cost Ration (BCR)}

Nilai Benefit Cost Ratio (BCR) merupakan perbandingan penerimaan dan biaya, dimana total penerimaan pertahun sebesar Rp. 75.600 .000 dan biaya total $\mathrm{Rp}$. 55.286 .000 sehingga menghasilkan 1,36. Karena nilai BCR > 1 , maka industri rumahan gula semut di Kelurahan Pallantikang ini layak untuk terus dijalankan. Adapun perhitungannnya dapat dilihat pada tabel berikut :

Tabel 7. Nilai BCR

\begin{tabular}{lr}
\hline \multicolumn{1}{c}{ Uraian } & Nilai/Tahun (Rp) \\
\hline Total Pendapatan & 75.600 .000 \\
Total Biaya & 56.993 .000 \\
\hline BCR & 1,32 \\
\hline
\end{tabular}

\section{Nilai Net Present Value (NPV)}

Metode ini berdasarkan pada nilai waktu dari uang, dengan demikian arus khas bersih yang didiskontokan atas dasar biaya modal atau investasi.

Berdasarkan hasil perhitungan Net Present Value (NPV) pada Tabel 8. menunjukkan bahwa pelaksanaan usaha gula semut di Kelurahan Pallantikang selama empat tahun (2013-2017) dinyatakan layak untuk dilaksanakan karena nilai NPV positif dengan tingkat suku bunga didasarkan pada bunga deposit yang berlaku di lembagalembaga keuangan. Dengan demikian dapat diartikan bahwa dana yang diinvestasikan industri rumahan gula semut di kelurahan Pallantikang sebesar Rp.27.616.000 dalam pelaksanaan usaha investasi tersebut dapat menghasilkan nilai sekarang arus kas (Present Value cost Flow) sebesar Rp. 
29.474.075. Adapun perhitungann NPV dapat dilihat pada Tabel 8.

\section{Nilai Internal Rate Of Return} (IRR)

Metode ini digunakan untuk menentukan besarnya tingkat menyamakan nilai sekarang dari arus kas yang diharapkan dimasa yang akan datang atau penerimaan kas dengan mengeluarkan investasi awal.. Dalam Penelitian ini nilai IRR (59\%) > bunga pinjaman (15\%) sehingga dikatakan bahwa industri rumahan gula semut di Kelurahan Pallantikang layak untuk melakukan investasi dan menjalankan operasional perusahaan. Perhitungan IRR dapat dilihat pada Tabel 9.

Tabel 8. Perhitungan NPV dengan Arus Kas Produksi Pada Industri Rumahan Gula

Semut di Kelurahan Pallantikang Tahun 2015

\begin{tabular}{|c|c|c|c|c|c|c|c|c|c|}
\hline Tahun & Biaxa Total & Inflasi & $\begin{array}{c}\text { Biaxa Total } \\
\text { Setelah } \\
\text { Inflasi }\end{array}$ & $\begin{array}{c}\text { Total } \\
\text { Pendapatan }\end{array}$ & $\begin{array}{c}\text { Laba } \\
\text { Sebelum } \\
\text { Pajak }\end{array}$ & Pajak & $\begin{array}{l}\text { Laba. } \\
\text { bersih }\end{array}$ & $\begin{array}{c}\text { DF } \\
(15 \%)\end{array}$ & $\begin{array}{c}\text { Present } \\
\text { Valye }\end{array}$ \\
\hline 0 & 27.616 .000 & & & & & & & & $-27.61 \% .000$ \\
\hline 1 & 56.993 .000 & 1.726 .888 & 58.719 .888 & 75.600 .000 & 16.880112 & $756.000^{\circ}$ & 16.124 .112 & 0,8696 & 14.021 .528 \\
\hline 2 & 56.993 .000 & 701.014 & 57.694 .014 & 75.6000 .0000 & 17.909 .986 & 756.000 & 17.149 .986 & 0,7561 & 12.463 .4800 \\
\hline 3 & 56.993 .000 & 416.049 & 57.409 .049 & 75.600 .000 & 18.190 .951 & 756.000 & 17.434 .951 & 0,6575 & $111.463 .480^{\circ}$ \\
\hline 4 & 56.993 .000 & 416.049 & 57.409 .049 & 75.600 .000 & 18.190 .951 & 756.000 & 17.434 .951 & 0,5718 & 9.969 .305 \\
\hline 5 & 56.993 .000 & 416.049 & 57.409 .049 & 75.600 .000 & 18.190 .951 & 756.000 & 17.434 .951 & 0,4972 & 8.668 .658 \\
\hline & & & \multicolumn{6}{|c|}{ Total PV } & 57.0 : 0.075 \\
\hline & & & \multicolumn{6}{|c|}{ NPV } & $\begin{array}{c}\vdots 29.4 \% 4.075 \\
\end{array}$ \\
\hline
\end{tabular}

Tabel 9. Perhitungan IRR dengan Arus Kas Produksi Pada Industri Rumahan Gula Semut di Kelurahan Pallantikang Tahun 2015

\begin{tabular}{|c|c|c|c|c|c|}
\hline \multirow[t]{2}{*}{ Tahun } & \multirow[t]{2}{*}{ kas bersih } & \multicolumn{2}{|c|}{ Bunga 15\% } & \multicolumn{2}{|c|}{ Bunga $60 \%$} \\
\hline & & DF & PV Kas Bersih & DF & $\begin{array}{l}\text { PV Kas } \\
\text { Bersih }\end{array}$ \\
\hline 1 & 16.124 .112 & 0,8696 & 14.021 .528 & 0,6667 & 10.749 .945 \\
\hline 2 & 17.149 .986 & 0,7561 & 12.463 .480 & 0,4444 & 7.621 .454 \\
\hline 3 & 17.434 .951 & 0,6575 & 11.463 .480 & 0,2963 & 4.277 .076 \\
\hline 4 & 17.434 .951 & 0,5718 & 9.969 .305 & 0,1526 & 2.660 .574 \\
\hline \multirow[t]{5}{*}{5} & 17.434 .951 & 0,4972 & 8.668 .658 & 0,0954 & 1.663 .294 \\
\hline & & Total PV & 57.090 .075 & & 26.972 .343 \\
\hline & & Investasi & 27.616 .000 & & 27.616 .000 \\
\hline & & NPV & 29.474 .075 & & -643.657 \\
\hline & & IRR & & & $59 \%$ \\
\hline
\end{tabular}




\section{Nilai Break Evant Point (BEP)}

BEP adalah suatu analisis untuk menentukan dan mencari jumlah barang atau jasa yang harus dijual kepada konsumen pada harga tertentu untuk menutupi biaya-biaya yang timbul serta mendapatkan keuntungan. Berdasarkan perhitungan BEP diperoleh BEP dalam unit sebanyak 1356 bungkus pertahun berarti industri rumahan gula semut di Kelurahan Pallantikang sudah layak dan memperoleh keuntungan dikarenakan jumlah penjualan gula semut bertahunnya diatas titik impas yaitu 3.624 bungkus. Sedangkan pada perhitungan BEP dalam rupiah diperoleh Rp. 338.885 untuk pertahunnya, Rp.28.240 untuk perbulannya sedangkan Rp.1.129 untuk perharinnya berarti industri rumahan gula semut di Kelurahan Pallantikang sudah layak dan memperoleh keuntungan dikarenakan harga jual gula semut diatas titik impas yaitu satu bungkus seharga Rp.25.0000 bungkus. Tabel nilai BEP dapat dilihat dibawah ini :

Tabel 10. Nilai BEP

\begin{tabular}{ll}
\hline Uraian & Nilai /Tahun \\
\hline BEP dalam Unit & 1.356 \\
BEP dalam Rupiah & Rp. 338.885
\end{tabular}

\section{Perhitungan Pay Back Period} (PBP)

Payback Periode adalah teknik penilaian terhadap jangka waktu pengembalian investasi suatu usaha. Adapun data perhitungan PBP dapat dilihat pada Tabel 11.
Tabel 11. Nilai BPB

\begin{tabular}{lc}
\hline \multicolumn{1}{c}{ Uraian } & Nilai /Tahun \\
\hline Investasi & 27.616 .000 \\
Kas bersih (Proceed) & \\
Proceed Tahun 1 & 16.124 .112 - \\
\cline { 2 - 2 } $\begin{array}{l}\text { Sisa investasi Tahun 2 } \\
\text { Proceed Tahun 2 } \\
\text { Hasil }\end{array}$ & 11.491 .888 \\
& 17.149 .986 \\
& 0.67 \\
\hline PBP & Dikalikan 12 Bulan \\
\hline
\end{tabular}

Berdasarkan Tabel 11. nilai PBP diperoleh dari nilai investasi dibagi arus kas bersih (proceed) Tahun 1, sisa investasi tahun 2 tertutup oleh proceed tahun ke-2 dari sebesar Rp. 17.149.986 yaitu $\mathrm{Rp}$. 11.491 .888 dibagi $\mathrm{Rp}$. 17.149.986 diperoleh 0,64 bagian, jika dikalikan 12 bulan maka diperoleh 8 . Jadi, Pay Back Period investasi diperoleh 8 bulan atau 1 tahun 7 Bulan (Lampiran 3). Artinya investasi yang ditanam pada usaha gula semut yang sebesar Rp.27.6161.000 akan kembali dengan rentang waktu 1 tahun 8 bulan. Oleh karena itu usaha industri rumahan gula semut di Kelurahan Pallantikang layak untuk dilaksanakan yang disebabkan karena usaha tersebut mampu mengembalikan investasi sebelum umur usaha berakhir.

\section{KESIMPULAN}

Berdasarkan hasil penelitian dan pembahasan yang telah dilakukan, maka dapat diambil kesimpulan sebagai berikut :

1. Faktor-Faktor pengembangan usaha industri rumahan gula semut 
di Kelurahan Pallantikang Kabupaten Takalar seperti bahan baku, produksi, tenaga kerja dan pemasaran layak dikembangkan di daerah penelitian.

2. Usaha industri rumahan gula semut di Kelurahan Pallantikang layak dijalankan karena memiliki nilai BCR $>1$ yaitu 1,32, nilai NPV positif atau diatas 0 yaitu Rp.29.474.075, nilai IRR adalah sebanyak $59 \%>$ bunga pinjaman (15\%), nilai BEP menurut unit sebanyak 1.356 bungkus perhari < dari jumlah produksi yang dihasilkan dan nilai BEP menurut rupiah sebanyak Rp.333.881 pertahun < dari harga produk yang dijual, dan nilai BPB adalah 1 Tahun 8Bulan < umur usaha.

3. Strategi yang sangat dibutuhkan didaerah penelitian adalah meningkatkan pendapatan usaha dengan memasarkan produk yang bermutu, menjalin kerjasama dengan pemerintah Kabupaten Takalar dan melakukan pelatihan dan pembinaan kepada penyadap nira

\section{DAFTAR PUSTAKA}

David, Fred R.2009.Konsep Manajemen Strategi. Jakarta : Penerbit Salemba Empat

Heriyanto,N.M. Subiandono, E. Karlina, E.2011.Potensi Sebaran Nipah (Nipa Fruticans (Thumb.) Wurmb) sebagai Sumberdaya Pangan. Jurnal Penelitian Hutan dan
Konservasi Alam,(on line) vol 8, No.4(.http://forda-mof.org/files 102. Heriyanto-

Potensi_dan_Sebaran_Nipah_.pdf . Diakses 3 Juni 2014)

Kasmir dan Jakfar. 2005. Studi Kelayakan Bisnis. Jakarta : Badan penerbit Prenada Media Grup.

LSM MAP.2013.Data Penyebaran Tanaman Nipah Di Kabupaten Takalar.

Mujiningsih. M.I, 2013. Analisis Kelayakan Usaha dan Strategi Pengembangan Industry Kecil Tempe Di Kecamatan Matesih Kabupaten Karanganyar. (on line), (http://lib.unnes.ac.id. Diakses 26 Januari 2015)

Pasaribu, A. M. 2012. Kewirausahaan Berbasis Agribisnis. Yogyakarta: Andi Yogyakarta.

Rangkuti, Freddy. 2008. Analisis SWOT Teknik Membedah Kasus Bisnis. Jakarta: PT. Gramedia Pustaka Utama.

Riyadi, A. 2010. Nipah Membawa Berkah.

http://jurnalenergi.com/news/55nipahmembawa-berkah. diakses pada tanggal 18 November 2012.

Sumarno, 1997.Pembuatan Gula Super Putih dari Nira Nipah Melalui Proses Fosfatasi-Flotasi. (on line), (http://repository.ipb.ac.id, diakses 25 oktober 2013). 